\title{
Potansiyel Kullanıcı Gruplarının Mobil Pazarlamaya Yönelik Bariyerlerinin Stratejik Pazarlama Kararları Bağlamında Önceliklendirilmesi
}

\section{Prioritization of Mobile Marketing Barriers of Potential User Groups in The Context of Strategic Marketing Decisions}

\author{
Tutku Tuncalı Yaman, ${ }^{\mathrm{a}, *}$ P1nar Bacaksız ${ }^{\mathrm{b}}$ \\ ${ }^{a}$ Dr. Öğr. Üyesi, Beykent Üniversitesi, İktisadi ve İdari Bilimler Fakültesi, Yönetim Bilişim Sistemleri Bölümü, İstanbul/Türkiye. \\ ORCID: 0000-0002-2862-8380

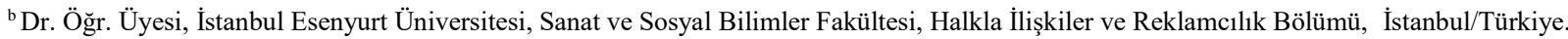 \\ ORCID: 0000-0003-4521-876X
}

\section{MAKALE BİLGİSI}

\section{Makale Geçmişi:}

Başvuru tarihi: 01 Eylül 2019

Düzeltme tarihi: 23 Kasım 2019

Kabul tarihi: 06 Aralık 2019

\section{Anahtar Kelimeler: \\ Mobil Pazarlama \\ Tüketici Davranışı \\ Risk Alg1sı \\ ÇKKV}

PROMETHEE

\section{ÖZ}

Çalışmanın amacı mobil internet kullanıcısı genç-yetişkin kitlenin karakteristik özelliklerini belirleyerek bu alt grupların mobil pazarlama fikrine karşı oluşturdukları bariyerler bağlamında işletmeler için stratejik olarak öncelikli aşılması gerekenlerin belirlenmesini sağlamaktır. $\mathrm{Bu}$ bağlamda hedef kitle tanımına uyan 220 internet kullanıcısı ile anket çalışması yapılmıştır. Çalışmada kişilerin demografik bilgilerinin yanı sıra mobil internet kullanım davranışları, cep telefonunu mobil pazarlama aracı olarak kullanmaları önündeki engeller ile mobil pazarlama fikrine yaklaşımları ölçülmüştür. Ölçekten elde edilen veriler faktör analizi ile beş ana değişkene indirgenmiş, bu değişkenler bağlamında yapılan değerlendirmelerin yanı sıra katılımcıların diğer özelliklerini içeren veri de kullanılarak kullanıcı profilleri oluşturulmuştur. Ardından işletmeler için profil bazında bariyer oluşturan faktörlerin öncelik ve önem sıralamasının belirlenebilmesi için PROMETHEE yönteminden yararlanılmıştır.

\section{ARTICLE INFO}

\section{Article history:}

Received 01 September 2019

Received in revised form 23 November 2019 Accepted 06 December 2019

\section{Keywords:}

Mobile Marketing

Consumer Behavior

Risk Perception

MCDM

PROMETHEE

\begin{abstract}
A B S T R A C T
The aim of this study is to identify the characteristics of the young and adult mobile Internet users and to determine barriers created by these groups against the idea of mobile marketing. It is known that these barriers are towards their marketing activities, which are conceived as the strategic priority for enterprises. In this context, an online-survey was conducted via Internet with 220 Internet users. With the collected data, in addition to the demographic information, mobile Internet usage behavior, the obstacles to using mobile phone as a mobile marketing tool and the approaches to mobile marketing idea were evaluated. Thanks to the 30 -item-scale in the questionnaire, attitude data towards mobile marketing were collected and were reduced to five main variables by factor analysis. Five user profiles were created by integrating these factors and characteristics data of the participants. Then, PROMETHEE method was used to determine the priority and importance ranking of the factors constituting a barrier on the basis of profile for the enterprises.
\end{abstract}

\section{Giriş}

Sürekli değişim gösteren ve dinamik bir yapının hâkim olduğu günümüz pazar koşullarında, teknoloji unsurunun yeri oldukça büyük önem arz etmektedir. İçinde bulunulan teknoloji çağı ve yoğun bilgi ağında, tüketicilerin farklılaşan tüketim alışkanlıkları ve iletişim biçimleri ile birlikte gelen ihtiyaç ve istekleri, yeni tüketici davranışlarına ve satın alma eğilimlerine yol açmaktadır (Terzi ve Kızgın, 2017: 200). İşletmeler, hem tüketicilerin bu beklentilerini daha

\footnotetext{
* Sorumlu yazar/Corresponding author

e-posta: tutkuyaman@beykent.edu.tr
} 
etkin ve verimli bir biçimde karş1layabilmek hem de temel amaçlarından olan kar elde etmek ve sürdürülebilirliği sağlamak durumundadırlar. Aynı zamanda da küresel boyutlarda anılan rekabette geri kalmamak, rekabette üstünlük sağlamak ve güç kazanmak için, teknolojik gelişmelere ayak uydurmak zorundadırlar (Şahin ve Dündar, 2019: 144). Bunun adına da farklı pazarlama yaklaşımlarına başvurmaktadır. Bunlardan biri olan ve mobil iletişim teknolojileri ile şekillendirilen mobil pazarlama anlayışı, rekabette üstünlük sağlamak isteyen işletmelere farklı kanalları sunarak, hedef kitlenin ihtiyaç ve isteklerini karşılamada yardımcı olmakta ve iletişim ağının gelişmesine katkıda bulunmaktadır.

Yapılan bu çalışmanın amacı, mobil pazarlama yaklaşımını uygulayan işletmelerin genç-yetişkin olarak tabir edilen hedef kitlesinin karakteristik özelliklerini belirleyerek, kullandıkları mobil pazarlama uygulamaları hakkındaki görüşlerini ve kullanım engellerini anlayabilmektir. Böylelikle işletmelere oluşturacakları pazarlama stratejileri ile orantılı mobil pazarlama anlayışlarının belirlenmesi sağlanacaktır. Bu noktadan hareketle, hedef kitle tanımına uyan 25-45 yaş arası ve eğitim seviyesi en az lise olan 220 internet kullanıcısı ile online bir anket çalışması yapılmıştır. Çalışmada kişilerin demografik bilgilerinin yanı sıra mobil internet kullanım amaçları, cep telefonunu mobil pazarlama aracı olarak kullanmaları önündeki engeller ile alanda yapılan literatür değerlendirmeye alınarak hazırlanan ölçek aracılığı ile mobil pazarlama fikrine yaklaşımları ölçülmüştür. 30 maddeden oluşan ölçekten elde edilen veriler faktör analizi ile beş ana değişkene indirgenmiş, bu değişkenler bağlamında yapılan değerlendirmelerin yanı sıra katılımcıların diğer özelliklerini içeren bilgiler kullanılarak kullanıcı profilleri oluşturulmuştur. Ardından işletmeler için profil bazında bariyer oluşturan faktörlerin öncelik ve önem sıralamasının belirlenebilmesi için çok kriterli karar verme (ÇKKV) yöntemlerinden biri olan PROMETHEE tekniğinden yararlanılmıştır. Çalışmada önerilen yaklaşım, mobil pazarlama işletmelerinin kullanıcı tabanını genişletmesi ve kullanıcı profili odaklı bir pazarlama stratejisi oluşturabilmesi için önemli bir girdi oluşturmaktadır. Böylece işletmeler için hedef müşteri kitlesinin ve belirlenen kitleye mobil pazarlama araçları ile ulaşmanın önündeki engellerin segment bazlı önceliklendirilmiş bilgisinin elde edilmesi yoluyla erişim alternatiflerinin profile göre çeşitlendirilmesi sağlanabilecektir. Faaliyet yelpazesi özellikle mobil internet kanallarından satış ve pazarlamaya odaklanan işletmeler için, henüz etkileşime geçmemiş yeni müşterilerin kazanımında önemli bir çözüm sunabilecek bu girdilerin kavramsal stratejilerin belirlenmesi yanı sira kural tabanlı pazarlama aracı olarak kullanılabilen karar destek sistemlerine de katkı sağlaması beklenmektedir.

Çalışmanın ilerleyen ikinci bölümünde güncel mobil pazarlama literatürü hakkında bilgi verildikten sonra, mobil pazarlama çalışmalarında hedef kitle ve müşteri segmentasyonunun yeri ile bu alanda yapılan çalışmalarda kullanılan çok kriterli karar verme tekniklerine değinilmiştir. Üçüncü bölümde ise araştırma yöntemi ve modeli açıklanmış, kullanılan yöntemle ilgili bilgi verilmiş, nihayet çalışma kapsamında gerçekleştirilen veri analizinden elde edilen tüm sonuçlar detaylandırılmıştır. Dördüncü ve son bölümde ise elde edilen sonuçlar işletme bakış açısıyla yorumlanmış ve gelecek araştırmalara yön verecek önerilerde bulunulmuştur.

\section{Mobil Pazarlama}

$\mathrm{Bu}$ bölümde öncelikle mobil pazarlama ve mobil reklamcılık kavramlarının tanıtımına yer verilecek, ardından mobil pazarlamada tüketici segmentasyonu ve hedef kitle belirlenmesinin önemi ile mobil cihaz kullanıcılarına yönelik olarak tasarlanan katma değerli servislerden; kısa mesaj (SMS), internet tarayıcısı, ses, mobil cihaz uygulamaları üzerinden alınan veya konum tabanlı veriyi kullanan pazarlama aksiyonları hakkında ÇKKV yöntemlerinin kullanımları üzerine mevcut literatüre yer verilecektir.

\subsection{Mobil Pazarlama ve Mobil Reklamcıl1k}

Hareket kabiliyeti, taşınabilirlik ve kablosuz iletim kavramlarını bir arada kullanan, bireylerin hareket halindeyken iletişim kurmasını ve bilgiye ulaşmasını sağlarken mobil olanaklar ve çözümler sunan teknolojilerin tümü, mobil iletişim teknolojileri olarak nitelendirilmektedir (Hesselborn ve Fremuth, 2005: 16). Temel özellikleri arasında ulaşılabilirlik, lokalizasyon ve kişiselleştirmenin de olduğu mobil iletişim teknolojileri aynı zamanda, mobil cihaz kullanıcıları arasında mesajların daha hızlı iletilmesini sağlayarak geniş bir paylaşım ortamı yaratan her çeşit iletişim aracı olarak da tanımlanmaktadır (Barutçu, 2011: 7).

Günümüz dünyasında tüketici kitleleri incelendiğinde her iki kişiden birinin mutlaka akıllı telefon kullanmakta olduğu ve 2,5 milyardan fazla kişinin mobil cihazları yoğun anlamda benimsediği anlaşılmıştır. Mobil teknolojilere rağbetin bu denli fazla olması, girişimcileri harekete geçiren nokta olmuştur (Bölen vd., 2018: 94).

Küreselleşmenin izlerinin yoğun şekilde hissedildiği bu teknoloji yoğun kullanımı bakımından değerlendirildiğinde, tüketicilerin mobil alışverişine yönlenmesindeki en büyük etkenlerden birinin de cihazların kullanım kolaylıklarının artması olarak belirlenmektedir (Uyar, 2019: 700).

İşletmeler hedef kitleleri ile sürekli iletişim halinde olabilmek, farklı bir haberleşme ve eğlence kanalı oluşturabilmek adına yeni bir pazarlama yaklaşımı geliştirmişlerdir. Mobil pazarlama adıyla anılan ve işletmelerin gözdesi haline gelen bu yaklaşım, zaman ve konum duyarlı bir kablosuz medyayı, tüketicilere ulaşmak ve ürünleri tanıtmak için, kişiselleştirilmiş iletişim stratejileri ile zenginleştirerek kullanan bir pazarlama etkinliği olarak görülmektedir (Scharl v.d. 2005: 160). Son yıllarda tüm dünyada bağlantı hızıyla birlikte doğru orantıda artan mobil araç kullanım oranı ile tüketicilerin bu araçlara bağımlı hale gelmesi, mobil pazarlamayı ön plana taşımıştır. Mobil araçlar vasıtasıyla, hedef tüketici kitlesine belirlenen ve istenilen zamanda mesajların iletilme olanağ sağlayan mobil pazarlama, işletmeler tarafindan son 20 y1lda en çok başvurulan stratejilerden biri haline gelmiştir (Michael ve Salter 2006: 13). Mobil araç kavramı denildiğinde mobil (kablosuz) telefonlar, tabletler ve dizüstü bilgisayarlar gibi cihazlar gelmektedir. Bu açıdan bakıldığında da mobil pazarlama çok sayıda mobil araca 
hizmet veren kablosuz iletişim araçlarının tamamını kapsayan bir pazarlama iletişimi vasıtasıdır.

Akıllı telefon teknolojileri ile hız kazanan mobil alışveriş, yeni bir akım yaratarak, perakende sistemlerinde de yeni bir döneme geçişi başlatmıştır (Kayıkçı vd., 2019: 2042).

Mobil iletişim araçları ile oluşturulan pazarlama stratejilerinde çok sayıda yöntem ve model mevcuttur. Bundan dolayı da mobil pazarlama yaklaşımı, kendi içerisinde çok farklı sınıflandırmaları barındırmaktadır. Nester vd. (2003)'nin yaptığı sınıflandırmada, mesaj tabanlı, internet tarayıcısı tabanlı, ses tabanlı, Java uygulamaları, sesli posta pazarlama ve konum tabanlı servisleri içeren gelişmekte olan teknolojiler ve teknikler, direkt pazarlama, özel promosyonlar, viral pazarlama, ambalaj üstü promosyon gibi başlıklar yer almaktadır. Özellikle mobil cihazlarda akıllı teknolojinin kullanılması ve yaygınlaşmasıyla konumlandırma teknolojileri gelişmiş, böylelikle de özellikle konum tabanlı reklamlar ön plana taşınmıştır (Bozacı ve Beğdeş, 2019: 2085). Bununla birlikte, Gardlund (2005) mobil pazarlama çalışmalarını reklam, değer katılmış servisler, etkileşim, oylama ya da anket, indirilebilir uygulamalar, bonuslar, oyunlar ve hatırlatıcılar olmak üzere 8 başlık altında toplamıştır.

Pazarlama iletişimi bileşenlerinden biri olan reklam, mobil pazarlamada da önemli bir yer teşkil etmektedir. Mobil pazarlamanın kalbi olarak nitelendirilen mobil reklamlar, sabit olmayan yani bir noktadan diğerine hareket eden ve mobil telefonlara gönderilen reklamlar olarak anılmaktadır (Barutçu ve Öztürk, 2009: 26). Ulaşılabilirlik, hedeflenmiş reklamcılık, mobil olma, çevreye uyumluluk ve esneklik, ölçeklenebilirlik, ölçümlendirilebilirlik gibi avantajları içeren mobil reklamcılık; Mobil Pazarlama Derneği’ne (2003) göre çeşitli mobil kanallar vasıtasıyla yapılan her türlü reklam ve pazarlama iletişimi aktivitesi olarak tanımlanmaktadır. Mobil reklamlar, tüketicilere özgü ve kişiselleştirmenin yoğun olarak hissedildiği mesajları içermesi bakımından çok daha kolay, etkili ve hılı bir şekilde mesajları iletebilmektedir. $\mathrm{Bu}$ sayede işletmeler tarafından geleneksel reklam mecralarına göre çok daha avantajlı olarak görülmektedir (Xu, Liao ve Li, 2008: 710724). Mobil reklamcılıkta, metin mesajlarını içeren kısa mesaj uygulamalarının yani SMS'lerin yanı sıra, video, ses, görüntü gibi içerikleri barındıran ve WAP teknolojisi gerektiren multi mesaj servisleri de denilen MMS mesajları da kullanılmaktadır (İspir ve Süher, 2009: 6).

\subsection{Mobil Pazarlamada Tüketici Segmentasyonu ve Hedef Kitle}

İşletme literatüründe oldukça eski zamanlara ve köklü kaynaklara dayanan Pazar bölümlendirme, mikroekonominin fiyat ayrıştırma modellerini baz almaktadır. Buna göre, karmaşık özelliklerin bir arada olduğu heterojen pazarlarda farklı fiyat stratejileri ile benzer ürünlerin arzı söz konusudur. (Wedel ve Kamakura, 2000:98). Bu noktadan hareketle Pazar bölümlendirme, benzer ilgi seviyelerinin ve ihtiyaçların aynı takımlara ayrılma süreci olarak nitelendirilebilir (McDonald ve Dunbar, 2004:179). Pazar bölümlendirme, tüketicilerin eş veya benzer özelliklerini gruplandırma seti olarak da belirtilmektedir. (Steenkamp ve Hofstede, 2002). İlk pazar bölümlendirme kriterlerinde tek bir demografik nitelik ya da ürünün satın alınma ve kullanılma derecesi ön planda tutulmuştur. Zamanla daha çok nitelik bir arada kullanılmaya başlanmış ve post-hoc ölçümleri geliştirilmiştir. Gelişen bu kriterlerle pazar bölümlendirme genel ve etki alanına özel olmak üzere farklı boyutlarla incelenmeye başlanmıştır (Wedel ve Kamakura, 2000:98). Bağımsız olarak nitelendirilen genel kriterler, demografik ve ekonomik göstergeler gibi gözlenebilir olabileceği gibi, tüketici yaşam tarzı ve değerleri gibi gözlenemeyen nitelik de taşıyabilmektedir. Etki alanına özel kriterler ise, tutumlar ve algıları içermektedir.

Pazar bölümlendirmenin temel yaklaşımlarından biri, esas kriterlerin belirlenip, modellenmesiyle kullanılacak stratejilerin belirlenmesidir. Bir başka yaklaşım ise, bu stratejilerin uygulanabilir hale getirilerek, teoriden pratiğe geçişinin sağlanması yönündedir (Haghirian ve Dickinger, 2004:10). Bu yaklaşımlar da en önemli nokta, kullanılacak analiz tekniğine en iyi şekilde karar verilebilmesidir. Wind ve Bell (2007); sınıflandırma yöntemleri (kümeleme), diskriminant yöntemleri (diskriminant ve regresyon), eş zamanlı değerlendirme (çok boyutlu ölçeklendirme), simülasyon ve optimizasyon (konjoint), Bayesyen yöntemler (modelleme) ve müşteriler arası etkileşim (veri madenciliği) olarak pazar bölümlendirmede kullanılan altı farklı analiz tekniği ortaya koymuştur.

Farklı pazar bölümlendirme yöntemleri kullanılarak özellikle mobil pazarlama stratejilerinde ve mobil reklamcılık faaliyetlerinde uzun dönemli karları hedefleyen işletmeler söz konusu olmaktadır. Yoğun şekilde yapılan Pazar araştırmaları sonucunda da mobil pazarlamanın Pazar bölümlendirme ile daha iyi sonuç verdiği ortaya konulmuştur. Bunlardan biri de O'regan, Ashok, Maksimova, Reshetin (2011) bir mobil telefon hizmet sağlayıcının hem farklı ülkelerdeki müşterilerine anket yaparak hem de veri madenciliği yoluyla bilgi toplayarak yaptığı mobil telefon pazarında ülkeleri pazar bölümlendirmedir. Bölümlendirme kriterleri olarak; tutumlar, algılar, davranışlar, demografik, kullanım, tüketicilerin harcama miktarları belirlenmiştir. Yazarlara göre bölümlendirme fatura veri tabanındaki davranışlar ve anket araştırmasındaki hem ihtiyaçlar hem de tutumlar tarafından yönlendirilmektedir. Yani çalışmada hem davranışsal hem de tutumsal bölümlendirme pazar bölümlerini tanımlamak için önerilmektedir.

Çok çeşitli yöntemler ve analizlerle yapılan pazar bölümlendirme kriterleri ile hedef pazarları seçmek işletmeler açısından daha efektif ve optimal sonuçlar vermektedir.

\subsection{Mobil Pazarlamada Çok Kriterli Karar Verme Yöntemleri}

Mobil pazarlama literatürü incelendiğinde ÇKKV yöntemlerinin uygulamada çok yoğun olarak kullanıldığ görülmemektedir. Örneğin Yılmaz, Başar ve Pabuçcu (2015)'nun TOPSIS ve analitik hiyerarşi süreci (AHS) ile kış turizmi otellerinin mobil pazarlaması yaklaşımı değerlendirilmiştir. Sanal mağazaların web sitelerinin değerlendirilmesinde Fuzzy Topsis yönteminin kullanıldığı Dündar, Ecer ve Özdemir (2007) çalışması, Göral (2015)'in AHP temelli TOPSIS yönteminin kullanıldığı E-WOM konulu çalışması bulunmaktadır. 
Ayrıca Kalburan (2018) bulanık AHS, TOPSIS ve çok boyutlu ölçekleme tekniklerini birleştirerek yeni bir yöntem önerisini cep telefonu markaları örneği ile göstermiştir. Bu çalışmalar mobil pazarlamada kullanılan ÇKKV tekniklerine örnek olarak verilebilmektedir. Literatüre bakıldığında mobil pazarlama kullanıcılarının segmentasyonu ile pazarlama profesyonelleri için aksiyona dönük olarak ÇKKV yöntemlerinin uygulamasına rastlanmamaktadır. Ayrıca daha önce PROMETHEE yönteminden de yararlanılmamıştır. $\mathrm{Bu}$ yönüyle yapılan bu çalışmanın pazarlama literatüründe de özgün bir nitelik kazandırdığg düşünülmektedir.

\section{Yöntem}

Çalışmanın bu bölümünde araştırmanın amacı ve önemi, evren ve örneklem bilgisi, araştırmada kullanılan veri toplama araçları ve söz konusu araçların geçerliliği ve güvenirliliği, araştırma modeli ve araştırmada kullanılan analiz tekniklerinin tanıtılmasına yer verilmiştir.

\section{1. Çalışmanın Amacı ve Önemi}

Güncel mobil pazarlama uygulamaları ve kullanıcı profillerinin yapılan aktivitelerin etkisini arttırmada ve hedef gruplara erişimdeki önemini göz önünde bulundurularak tasarlanan bu çalışmanın temel amacı mobil pazarlama aracılığı ile bu kanalı kullanan işletmelerin hedef kitlesini oluşturan mobil internet kullanıcısı genç-yetişkin kitlenin karakteristik özelliklerini belirleyerek; segmentasyon (bölümlendirme) ile elde edilecek bu alt grupların mobil pazarlama fikrine karşı oluşturdukları bariyerlerin anlaşılması ve işletmeler için stratejik olarak öncelikli aşılması gereken bariyerlerin tespit edilmesidir. $\mathrm{Bu}$ amaç doğrultusunda öncelikle mobil internet kullanıcısı kitlenin kullanım alışkanlıkları ve tutumları bağlamında kullanıcı profilleri oluşturulmuştur. Daha sonra kullanıcılar bu profiller bazında segmentlere ayrılmıştır. Segmentlerin karakteristikleri, ilgili segmentte temsil edilen kişilerin mobil pazarlama aktivitelerine bakış açıları ve yapılan mobil pazarlama aktivitelerine karşı olumsuz bir tutum almalarına neden olan bariyerler bağlamında tanımlanmıştır. Ardından bu profiller için çok kriterli karar verme yöntemlerinden olan PROMETHEE (The Preference Ranking Organization METHod for Enrichment Evaluation) ile bu bariyerlerin her profil için önem seviyesi belirlenmiştir. Bu sonuçlar mobil pazarlama profesyonelleri için hedef kitlelerine ulaşmada ilk olarak hangi engellerin ortadan kaldırılması ve ne tip aksiyonlar alınması gerektiğine dair bir fikir verecektir.

İlerleyen bölümde öncelikle çalışmanın metodolojisine yer verilecek ve uygulamada kullanılan PROMETHEE yöntemi açıklanacaktır.

\subsection{Evren ve Örneklem}

İnternet farklı demografik özelliklere sahip kullanıcıların bulunduğu çevrimiçi ortamları içermektedir. $\mathrm{Bu}$ araştırmanın evrenini, Türkiye'deki farklı demografik özelliklere sahip ve bir yıldan uzun süredir cep telefonu sahibi olan tüketiciler oluşturmaktadır. Toplum bilimlerinde, genellikle, her gözenekte bulunacak ve normal bir dağılımı temsil edecek örnek miktarının, 300, 400 dolaylarında olmasının ideal, fakat 100 'den de aşağı düşmemesinin yararlı bir uygulama olacağı söylenebilir. Araştırmacı,
' 'büyük örnek' yerine ''iyi örnek' seçmeyi amaç edinmelidir (Karasar, 2005:127). Bu bilgiler 1şı̆̆ında ve evrenin tamamına ulaşmak mümkün olmadığından evreni temsil eden 220 kişilik örneklem seçilmiştir.

\subsection{Veri Toplama Araçları}

Çalışmanın veri toplama aracı, amacını destekleyecek şekilde oluşturulan ve 3 bölümden meydana gelen anket formudur. Formun ilk bölümü katılımcıların demografik özelliklerini içeren "Demografik Form", ikinci bölüm internet kullanımı ve cep telefonu üzerinden aldığı hizmetlerin detayını ve kullanımdaki olası bariyerleri içeren "Kullanım Alışkanlıkları Formu”dur. Son bölümde ise pazar bölümlendirmesi amacı ile kullanılacak "Mobil Pazarlama Tutum Ölçeği” bulunmaktadır. Ölçek, Doğaner ve Kuyucular (2017), Tsang, Ho ve Liang (2004) çalışmaları ve literatürde konu ile ilgili yayınlardan derlenerek oluşturulmuştur. Literatürden derlenen ölçek ifadeleri 3 sektör profesyoneline de kontrol ettirilerek geri dönüşleri alınmıştır. Anket uygulamasına geçilmeden önce örneklem özelliklerini taşıyan 30 kişiye yüz yüze uygulanarak pilot çalışma yapılmıştır. Sonrasında soru formunda herhangi bir aksaklık bulunmadığı görüldüğünden ana veri toplama aşamasına geçilmiştir. Bu kapsamda potansiyel 500 kişiye, internet üzerinden ulaşabilecekleri soru formunu içeren link ve araştırmayı tanıtıcı yazıyı içeren bir e-posta gönderilmiştir. İki aylık süre sonucunda toplam 243 kişiden geri dönüş alınmıştır. Soruların cevaplanma durumu kontrol edildikten sonra eksiklikleri nedeni ile 23 adedi elenmiş ve analizler için 220 adedinin kullanılması uygun görülmüştür. Araştırmanın veri toplama aşaması Kasım - Aralık 2018 tarihlerinde tamamlanmıştır.

\subsection{Araştırma Modeli}

Çalışma amacına paralel olarak önerilen araştırma modeli (Şekil 1) yukarıda kısaca özetlendiği gibi öncelikle mobil internet kullanıcısı kitlenin kullanım alışkanlıkları ve tutumları bağlamında bölümlendirilmesi adımı ile başlamaktadır. Bu bağlamda 30 maddeden oluşan "Mobil Pazarlama Tutum Ölçeğì"nin 220 kişilik örneklemin 5'li likert ölçeği (5:Tamamen Katılıyorum, 4:Katılıyorum, 3:Fikrim Yok, 2:Katılmıyorum ve 1:Hiç Katılmıyorum) aracılığı ile değerlendirmesinden elde edilen veri ile yapısal geçerliliğinin sınanması amacıyla açıklayıcı faktör analizi uygulanmıştır. Açıklayıcı faktör analizi, araştırmacının tek bir veri setindeki hangi değişkenlerin bir diğerlerinden nispeten bağımsız olarak tutarlı alt kümeleri oluşturduğunu keşfetmeye ilgi duyduğunda kullandiğ istatistiksel bir tekniktir. Birbiri ile ilişkili olan, fakat büyük ölçüde değişkenlerin diğer alt kümelerinden bağımsız olan değişkenler, faktörler olarak birleştirilirler. Faktörlerin değişkenler arasındaki korelasyonları oluşturan temel süreçleri yansıttıkları düşünülür (Tabachnick ve Fidell, 2013:612). Açıklayıcı faktör analizi öncesi Kaiser Meyer Olkin (KMO) örnekleme yeterliliği değeri ile Bartlett küresellik test istatistikleri denetlenmiştir. Çalışmada kullanılan ölçeğin KMO değeri 0,918, Bartlett küresellik test istatistiği ise $\chi^{2}: 2911,857$, s.d.:435, p:0,00 olarak bulunmuştur. KMO değeri ölçeğin oldukça yüksek bir örnekleme yeterliliğine sahip olduğu ve Bartlett küresellik testi bulguları ise ölçek maddelerinin birlikte bir 
olguyu ölçmek için yeterli düzeyde korelasyon ilişkileri içinde olduğunu göstermiştir. Ölçeğin güvenirlilik düzeylerinin belirlenmesi amaciyla ise Cronbach's Alpha güvenirlilik analizi de uygulanmıştır. Cronbach's Alpha değeri bir ölçekteki soruların varyanslarının toplamının genel varyansa bölünmesi ile elde edilir. Alfa değeri ile bir ölçekteki soruların, belirli gruplar halinde, türdeş bir yapıyı oluşturup oluşturmadıkları belirlenmeye çalışılır. 0 ile 1 arasında değer alan alfa değerinin negatif çıkması, güvenirliliğin bozulduğu anlamına gelir (Karagöz, 2015:94). Ölçeğe ait Cronbach's Alpha değeri 0,903 olarak bulunmuş ve devamındaki analizler için yeterli olduğu görülmüştür. Mobil Pazarlama Tutum Ölçeği'nin güvenilirliği ve geçerliliği sınandıktan sonra ölçekten elde edilen verilerin faktör analizi aracılığı ile kullanıcı gruplarını belirlemede yeterli olduğu görülmüştür. Belirlenen grupların detaylı olarak tanımlanarak incelemesine veri analizi bölümde yer verilecektir.

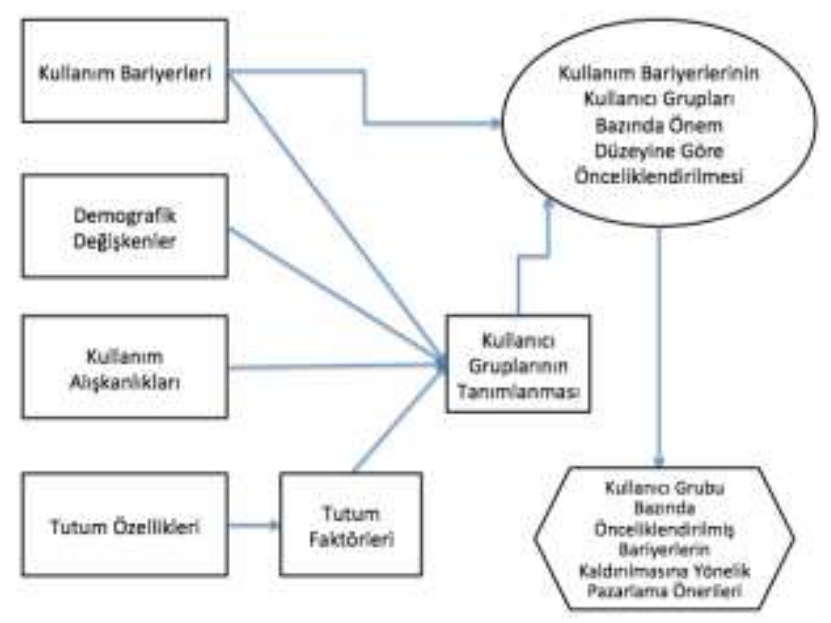

Şekil 1. Araştırma Modeli

Çalışma kapsamında önerilen metodoloji için kullanıcı gruplarının belirlenmesinden sonraki adım bu gruplar bazında mobil pazarlama aktivitelerine karşı oluşan bariyerlerin ortadan kaldırılmasında hedef kitle bazında önceliklendirme yapılmasını sağlamak amacı ile çok kriterli karar verme (ÇKKV) yöntemlerinden PROMETHEE'nin kullanılmasıdır. Yöntem Jean Pierre Brans (1982) tarafindan mevcut alternatiflerin kısmi ve tam sıralamasını ele alan iki ayrı yaklaşım olarak önerilmiştir. Sonrasında aralıkları temel alan sıralama, sürekli durumlar için uygulama, bölümlendirme kısıtlarını içeren uygulama ve insan beyni temsili uygulama da dahil olmak üzere altı farklı tür geliştirilmiştir (Dağ ve Yıldırım, 2015:177). Yöntem, ele alınan problem bağlamında optimal alternatifin seçiminden ziyade bunlar arasında siralama yaparak karar alıcının amacına göre bir değerlendirme yapmasına olanak sağlamaktadır. Yöntemin uygulamasında karar alıcı tüm değerlendirme kriterleri için ikili karşılaştırmalarda önceliği belirlemeli ve her kritere verdiği önemi oran ölçek üzerinden değerlendirmelidir. Yöntem, pek çok ÇKKV yönteminde de olduğu gibi, her kriter için gerekli ağırlık değerlerinin önsel olarak elde edilmesini gerektirir. Bir seçenek olarak bu ağırlıklar ELECTRE (Élimination et Choix Traduisant La Réalité) ve TOPSIS (Technique for Order Preference by Similarity to Ideal Solution) yaklaşımlarındaki gibi Analitik Hiyerarşi Süreci’nin (AHP) önem ölçeği yaklaşımıyla belirlenebilir. Belirlenen ağrılıkların pozitif ve toplamlarının 1 (\%100) olması gerekir.

PROMETHEE yöntemi her kriter için ayrı bir tercih fonksiyonu $(\pi)$ tanımlaması yaparak bu fonksiyonları alternatiflerin ikili karşılaştırmalarında kullanır. Bu tercih fonksiyonu temelde iki alternatif arasındaki farklı, bu bağlamda tercih derecesini ifade eder. Tercih fonksiyonu yapısı karar alıcıya yardımcı olmak için önceden belirlenmiş modeller arasından duruma uygun olanın seçimi ile belirlenir. Farklı tercih fonksiyonu türleri için Brans ve Mareschal'ın (2005:170) çalışması incelenebilir. $n \times n$ boyutlu ve elemanları $0-1$ arasında değerler alabilen tercih fonksiyonundan hareketle herhangi iki alternatif için elde edilen değerlerin değerlendirmesi aşağıdaki gibi yapilmaktadır;

$\pi_{j}(1,2)=0 \rightarrow$ j'inci kriter için 1 ve 2.'nci alternatifin arasında fark yoktur.

$\pi_{j}(1,2) \approx 0 \rightarrow$ j'inci kriter için 1'inci alternatif 2'nciye göre daha az tercih edilmektedir.

$\pi_{j}(1,2) \approx 1 \rightarrow$ j'inci kriter için 1'inci alternatif 2'nciye göre daha fazla tercih edilmektedir.

$\pi_{j}(1,2)=1 \rightarrow$ j'inci kriter için 1 'inci alternatif 2 'nciye göre tam olarak tercih edilmektedir.

Yukarıdaki fonksiyonlar aracılığı ile tercih indeksleri belirlendikten sonra alternatifler arasında siralama yapabilmek için $\mathrm{n}$ adet alternatif için pozitif ve negatif üstünlük akımları hesaplanır. Pozitif akımların bulunması için Denklem 1'den, pozitif akımların bulunması için ise aşağıdaki Denklem 2'den yararlanılır.

$$
\begin{aligned}
\phi^{+}(a) & =\frac{1}{n-1} \sum_{x \in A} \pi(a, x) \\
\phi^{-}(a) & =\frac{1}{n-1} \sum_{x \in A} \pi(x, a)
\end{aligned}
$$

Pozitif üstünlük akımı herhangi bir alternatifin diğer tüm alternatiflere nasıl üstünlük sağladığının, negatif üstünlük akımı ise tersine nasıl bastırıldığının göstergesidir. Herhangi bir alternatifin pozitif akımının yüksek, negatif akımının düşük olması onu tercih edilir kılar. Karar sürecinde tüm alternatifleri sıralayabilmek için bu akımlar karşılaştırılır. Karşılaştırma amaçlı olarak pozitif ve negatif akım değerleri toplanarak net akım değeri $\left(\phi_{N E T}\right)$ de elde edilebilir. PROMETHEE I kısmı karşılaştırma yaparken tüm alternatiflerin karşılaştırılabilmesi için PROMETHEE II yaklaşımından yararlanılır. Sonuçların görselleştirilmesinde karar alıcıya kolaylık sağlayan GAIA düzlemi adı verilen grafikler de kullanılmaktadır. Yöntemin uygulaması ve GAIA düzleminin oluşturulması adımlarının kolaylıkla gerçekleştirilebildiği Decision Lab, Visual PROMETHEE, D-Sight gibi paket programlar bulunmaktadır (Genç, 2013:135-148). Bu çalışmada da veriler Visual PROMETHEE (Mareschal ve De Smet, 2009) ile analiz edilmiş, sonuçlara veri analizi bölümünde detaylı olarak yer verilmiştir.

\subsection{Veri Analizi}

$\mathrm{Bu}$ bölümde öncelikle örneklem ile ilgili demografik ve kullanım alışkanlıklarına dair değişkenlerin dağılımlarına yer verilecek ardından "Mobil Pazarlama Tutum Ölçeği" temel alınarak faktör analizi aracılığı ile yapılan 
bölümlendirme (segmentasyon) sonuçlarına değinilecektir. Oluşturulan potansiyel kullanıcı gruplarının kullanım alışkanlıkları ve demografik özellikler bağlamında tanımlanmasının ardından bu grupların mobil pazarlamaya yönelik bariyerlerinin önceliklendirilmesine yönelik olarak yapılan PROMETHEE sonuçları açıklanacaktır. Çalışma kapsamında toplanan tüm veriler SPSS (Statistical Package for Social Sciences) v.20 paket programı ile işlenmiş ve PROMETHEE dışındaki tüm analizler bu program ile yapılmıştır.

\subsubsection{Tanımlayıcı İstatistikler}

Çalışmanın örneklemini oluşturan 220 kişiye ait tanımlayıcı istatistiklere Tablo 1'de detaylı olarak yer verilmiştir. Buna göre katılımcıların \%74'ü kadın \%26'sı erkektir. Çoğunluğu 31-40 yaş arası (\%58), kamu veya özel sektörde ücretli çalışanlar oluşturmaktadır. Genel olarak eğitim seviyesinin yüksek olduğu görülmektedir.

Tablo 1. Demografik Özellikler

\begin{tabular}{clcc}
\hline & \multicolumn{1}{c}{ Demografik Özellikler } & f & $\%$ \\
\hline \multirow{2}{*}{ Cinsiyet } & Kadın & 162 & 73,6 \\
& Erkek & 58 & 26,4 \\
\hline \multirow{3}{*}{ Yaş } & 30 ve altı & 72 & 32,7 \\
& $31-40$ & 128 & 58,2 \\
& 41 ve üstü & 20 & 9,1 \\
\hline \multirow{5}{*}{ Meslek } & Kamu kurumunda ücretli & 102 & 46,4 \\
& Özel sektörde ücretli & 86 & 39,1 \\
& Serbest meslek & 16 & 7,3 \\
& Esnaf veya tüccar & 4 & 1,8 \\
& Diğer (Öğrenci, işsiz, vb.) & 12 & 5,5 \\
\hline \multirow{2}{*}{ Eğitim } & On lisans ve lisans & 160 & 72,7 \\
durumu & Yüksek lisans & 50 & 22,7 \\
& Lise & 10 & 4,5 \\
\hline
\end{tabular}

Kullanım alışkanlıklarına ilişkin detaylar Tablo 2'de gösterilmiştir. Buna göre \%73'lük bir çoğunluğun aynı zamanda evinde de internet bağlantısı bulunmaktadır. $\% 41$ 'lik bir grubun işyerinde internet kullanımı kisitlanmaktadır. \%78'inin telefonu 4,5G mobil internet bağlantısını destekleyecek özelliktedir. Cep telefonları üzerinden yapılan aktivitelere bakıldığında ise katılımcıların cep telefonlarını en çok "Başkaları ile sohbet etmek" (\%62) amacı ile kullandıkları görülmektedir. Bunu "Haberleri takip etmek" (\%59), "Rezervasyon yaptırmak, bilet satın almak" (\%54), "Yönlendirme ve bilgilendirme hizmetleri (trafik, hava durumu vb.)" (\%53) takip etmektedir. Alış veriş alışkanlıklarına ilişkin tercihlere bakıldığında ise en fazla giyim ürünlerini (\%35) almak için cep telefonlarını kullandıkları görülmektedir. Bunu kitap ve eğitim araçları ile bebek ve çocuk ürünleri izlemektedir.

Katılımcılardan cep telefonlarında karşılarına çıkan reklam vb. pazarlama faaliyetleri sonrasında ürünü satın almalarına yönelik bir aksiyon almalarına engel olan bariyerlerin neler olduğunu değerlendirmeleri istenmiştir. Buna göre katılımcılar açısından en öne çıkan bariyer "Satın alma işlemi sırasında verilen kişisel bilgilerin üçüncü şahıslarla paylaşılma riski” (\%75) olarak öne çıkmaktadır. Diğer bir önemli bulgu ise yaklaşı \%35'lik bir grubun cep telefonlarını internetten alışveriş yapmak amaçlı kullanmadıklarını iletmesidir.

\subsubsection{Pazar Bölümlendirme (Segmentasyon) Analizi}

Potansiyel kullanıcı profillerini oluşturmak üzere çalışmada kullanılan "Mobil Pazarlama Tutum Ölçeği”, aracılığı ile toplanan veriler faktör analizine tabi tutulmuştur. Ölçeğin geçerliliği ve güvenilirliğine ilişkin değerlendirme daha önce açıklandığı için bu aşamada sadece faktör analizi sonuçlarına yer verilmiştir. Ölçeğe serbest sayıda faktöre izin verilerek Varimax rotasyonu ile yapılan açıklayıcı faktör analizi sonuçlarına bakıldığında ölçek maddelerinin beş boyutta toplandığ1 görülmüştür. Ayrıca Tablo 4'den izlenebileceği üzere birinci bileşen tek başına ölçek varyansının \%24,58'ini, ikinci yaklaşık \%24'ünü, üçüncü \%11,6'sın1, dördüncü \%7,06'sını ve beşinci ise \%5,1'ini açılamakta; kümülatif varyans açıklama yüzdesinin ise oldukça yüksek ve $\% 72,39$ olduğu görülmektedir. Her bileşen için tanımlayıcı ölçek maddelerine ait olan faktör yüklerinin işaretleri ve maddelerin kavramsal anlamlılığı göz önünde bulundurularak bileşenlerin birer potansiyel kullanıcı grubu olabileceği görülmüş ve bu gruplar şu şekilde isimlendirilmiştir.

Tablo 2. Kullanım Alışkanlıkları

\begin{tabular}{|c|c|c|c|}
\hline \multicolumn{2}{|r|}{ Kullanım Alışkanlıkları } & $\mathrm{f}$ & $\%$ \\
\hline \multirow{2}{*}{$\begin{array}{c}\text { Evde } \\
\text { internet } \\
\text { bağlantısı }\end{array}$} & Var & 162 & 73,6 \\
\hline & Yok & 10 & 4,5 \\
\hline \multirow{2}{*}{$\begin{array}{c}\text { Cep } \\
\text { telefonunda } \\
4,5 \mathrm{G} \\
\end{array}$} & Var & 172 & 78,2 \\
\hline & Yok & 48 & 21,8 \\
\hline \multirow{2}{*}{$\begin{array}{l}\text { İşyerinizde } \\
\text { internet } \\
\text { kullanımına } \\
\text { ilişkin } \\
\text { kisıtlama } \\
\end{array}$} & Var & 90 & 41,3 \\
\hline & Yok & 128 & 58,7 \\
\hline \multirow{16}{*}{$\begin{array}{c}\text { Cep } \\
\text { telefonu } \\
\text { üzerinden } \\
\text { kullanilan } \\
\text { hizmetler }\end{array}$} & Haberleri takip etmek & 130 & 59,1 \\
\hline & $\begin{array}{l}\text { Bilgisayar ve bilgisayar ürünleri } \\
\text { satın almak }\end{array}$ & 10 & 4,5 \\
\hline & $\begin{array}{l}\text { Futbol, basketbol vb. spor } \\
\text { müsabakalarını izlemek }\end{array}$ & 10 & 4,5 \\
\hline & Mobil telefon satın almak & 8 & 3,6 \\
\hline & Elektronik ürünler almak & 10 & 4,5 \\
\hline & $\begin{array}{l}\text { Rezervasyon yaptırmak, bilet } \\
\text { satın almak }\end{array}$ & 118 & 53,6 \\
\hline & Başkaları ile sohbet etmek & 150 & 68,2 \\
\hline & Hediyelik eşya satın almak & 44 & 20,0 \\
\hline & $\begin{array}{l}\text { Kitap ve eğitim araçları satın } \\
\text { almak }\end{array}$ & 66 & 30,0 \\
\hline & $\begin{array}{l}\text { Yönlendirme ve bilgilendirme } \\
\text { hizmetleri (trafik, hava durumu } \\
\text { vb.) }\end{array}$ & 116 & 52,7 \\
\hline & Ev tekstili ürünleri almak & 36 & 16,4 \\
\hline & $\begin{array}{l}\text { Sağlık ürünleri almak (Tansiyon } \\
\text { aleti, buhar makinesi vb.) }\end{array}$ & 10 & 4,5 \\
\hline & $\begin{array}{l}\text { Beyaz eşya ve küçük ev aletleri } \\
\text { satın almak }\end{array}$ & 14 & 6,4 \\
\hline & Giyim ürünleri almak & 78 & 35,5 \\
\hline & $\begin{array}{l}\text { Bebek ve çocuk ürünleri almak } \\
\text { (Kıyafet, oyuncak, biberon vb.) }\end{array}$ & 66 & 30,0 \\
\hline & Film ve müzik kliplerini izlemek & 94 & 42,7 \\
\hline
\end{tabular}

Bileşen 1: Erken Benimseyenler (Early Adopters)

Bileşen 2: Düzenli Kullanıcılar (Regular Users)

Bileşen 3: Güvenliler (Trustworthy) 
Bileşen 4: Teknoloji meraklısı (Geek)

\section{Bileşen 5: Sıradışı (Out-of-the-box)}

Faktör analizi ile tutumlarına göre gruplandırılan bu kullanıcıların demografik özellikleri ve kullanım alışkanlıkları bağlamında incelenmesi ile potansiyel grupların detaylı tanımları yapılabilecektir. Bunun için elde edilen her gruba ait olan katılımcıların demografik özellikleri ve kullanım alışkanlıkları incelenmiştir. Grup bazında değerlendirme yapabilmek için her değişken bazında öne çıkan kategoriler tanımlayıcı özellik olarak kabul edilmiştir. $\mathrm{Bu}$ amaçla tespit edilen 5 kullanıcı grubunu kavramsal olarak tanımlamak için demografik özellikleri, kullanım alışkanlıkları ve potansiyel bariyerler ile ilgili öne çıkan özellikleri Tablo 5 'te verilmiştir. Her özellik bazında hangi grupta diğerlerine göre yüksek oranda tercih edilmiş olanlar ilgili grubun karakteristiği olarak kabul edilmiştir.

Buna göre "Erken Benimseyenler" grubunda cinsiyetin belirleyici bir özellik olmadığı, 40 yaş üstü ve lisans ve daha düşük eğitim seviyesine sahip kullanıcıların daha çok bulunduğu, diğer gruplara nazaran özel sektör çalışanlarının daha fazla yer aldığı görülmektedir. Farklılaşan kullanım alışkanlıklarına bakıldığında ise cep telefonlarını "Bilgisayar ve bilgisayar ürünleri satın almak" (\%40), "Rezervasyon yaptırmak, bilet satın almak" (\%24), "Hediyelik eşya satın almak" (\%27), "Sağlık ürünleri almak (Tansiyon aleti, buhar makinesi vb.)" (\%40), "Beyaz eşya ve küçük ev aletleri satın almak" (\%29) ve "Film ve müzik kliplerini izlemek" (\%26) amacıyla kullandıkları görülmüştür. Cep telefonu aracılığı ile internetten alışveriş yapmaya engel olan bariyerlere bakıldığında ise "Satın alınan mal ve hizmetlerin bedelini ödemede güvenlik açığı yaşanması” (\%31), “Cep telefonunun şarjının mobil uygulamaların kullanımında kısa surede tükenmesi" (\%28) ve "Cep telefonunun özelliklerini kullanma zorluğu" (\%27) öne çıkmaktadır. Bu gruptaki kullanıcıların \%21'i cep telefonunu internetten alışveriş yapmak amaçlı kullanmadığını belirtmektedir.

“Düzenli Kullanıcılar” grubunda daha çok genç yaş grubu kadın kullanıcıların bulunduğu, lisans ve daha düşük eğitim seviyesine sahip olanların öne çıktığı ve diğer gruplara nazaran daha fazla öğrenci ve işsiz (\%44) kişilerden oluştuğu görülmektedir. Farklılaşan kullanım alışkanlıklarına bakıldığında ise cep telefonlarını "Giyim ürünleri almak" (\%28), "Mobil telefon satın almak" (\%38), "Kitap ve eğitim araçları satın almak" (\%30), "Ev tekstili ürünleri almak" (\%33), "Sağl1k ürünleri almak (Tansiyon aleti, buhar makinesi vb.)" (\%40), "Beyaz eşya ve küçük ev aletleri satın almak" (\%29) ve "Bebek ve çocuk ürünleri almak (Kiyafet, oyuncak, biberon vb.)" (\%30) amaciyla kullandıkları görülmüştür. $\mathrm{Bu}$ gruptaki kullanıcıların hiçbirinin cep telefonunu "Bilgisayar ve bilgisayar ürünleri satın almak" için kullanmadığı ve diğer gruplarla karşılaştırıldığında telefonunu "Kitap ve eğitim araçları satın almak" için en çok kullanan segment olduğu görülmektedir. Cep telefonu aracılı̆̆ 1 ile internetten alışveriş yapmaya engel olan bariyerlere bakıldığında ise en çok "Satın alma işlemi sırasında verilen kişisel bilgilerin üçüncü şahıslarla paylaşılma riski” (\%23) diğer gruplardan farklı olarak öne çıkmaktadır. Bu gruptaki kullanıcıların \%18'i cep telefonunu internetten alışveriş yapmak amaçlı kullanmadığını belirtmektedir.
"Güvenliler" grubunda daha çok kadın kullanıcıların bulunduğu ve özellikle belirli bir yaş grubunun temsil edilmediği görülmüştür. Eğitim durumlarına bakıldığında diğer gruplardan daha fazla lisans üstü eğitimi almış (\%32) kişilerin yer aldığı ve serbest meslek mensuplarının tamamının bu grupta temsil edildiği söylenebilir. Farklılaşan kullanım alışkanlıklarına bakıldığında ise cep telefonlarını "Başkaları ile sohbet etmek" (\%21) ve "Giyim ürünleri almak" (\%22) için kullandıkları görülmüştür. Cep telefonu aracılığı ile internetten alışveriş yapmaya engel olan bariyerlere bakıldığında ise en çok "Telefon ekranının küçük olması" (\%25) ve "Mobil iletişim ücretlerinin yüksek olması" (\%25) diğer gruplardan farklı olarak öne çıkmaktadır. Burada diğer bir önemli bulgu ise "Satın alma işlemi sırasında verilen kişisel bilgilerin üçüncü şahıslarla paylaşılma riski” (\%15) ve "Cep telefonunun özelliklerini kullanma zorluğu” (\%0) bariyerleri bu grupta en düşük oranda belirtilen engellerdir. Bu gruptaki kullanıcıların \%16'sı cep telefonunu internetten alışveriş yapmak amaçlı kullanmadığını belirtmektedir.

“Teknoloji meraklısı" grubunda diğer gruplara göre daha çok 31-40 yaş arası (\%26) ve erkek (\%29)kullanıcıların bulunduğu görülmüştür. Eğitim durumlarına bakıldığında diğer gruplardan daha fazla lisans üstü eğitimi almış (\%34) kişilerin yer aldığı ve hem kamu hem özel sektörde ücretli çalışanların yoğunlukta olduğu tespit edilmiştir. Farklılaşan kullanım alışkanlıklarına bakıldığında ise cep telefonlarını "Bebek ve çocuk ürünleri almak (Kıyafet, oyuncak, biberon vb.)" (\%9) ve "Giyim ürünleri almak" (\%10) dışında hemen hemen her amaçla kullanmaktadırlar. Cep telefonu aracılığı ile internetten alışveriş yapmaya engel olan bariyerlere bakıldığında ise en çok "Mobil iletişim ücretlerinin yüksek olması" (\%32), "Satın alınacak mal ve hizmetleri değerlendirme zorluğu yaşanması" (\%30) ve "Satın alma işlemi sırasında verilen kişisel bilgilerin üçüncü şahıslarla paylaşılma riski” (\%25) diğer gruplardan farklı olarak öne çıkmaktadır. Bu gruptaki kullanıcıların \%16'sı cep telefonunu internetten alışveriş yapmak amaçlı kullanmadığını belirtmektedir.

Son olarak en düşük hacme sahip "Sıradışı" grubunu çoğunlukla düşük eğitim seviyesine sahip 30 yaş altı ve 41 yaş üstü erkek kullanıcılar oluşturmaktadır. Esnaf/tüccar meslek grubunun büyük çoğunluğu bu grupta temsil edilmektedir. Farklılaşan kullanım alışkanlıklarına bakıldığında ise cep telefonlarını çoğunlukla "TV izlemek - radyo dinlemek" (\%22) ve "Başkaları ile sohbet etmek" (\%19) amacı ile kullananların öne çıktığı tespit edilmiştir. Cep telefonu aracılığı ile internetten alışveriş yapmaya engel olan bariyerlere bakıldığında ise en çok "Cep telefonunun özelliklerini kullanma zorluğu” (\%18) diğer gruplardan farklı olarak öne çıkmaktadır. En önemli bulgulardan bir tanesi de bu gruptaki kullanıcıların \%29'unun cep telefonunu internetten alışveriş yapmak amaçlı kullanmadığını belirtmektedir ki bu değer diğer gruplara kıyasla en yüksek oran olarak ortaya çıkmaktadır.

Sonraki bölümde belirlenen kullanıcı grupları bazında mobil pazarlama için geri dönüş almaya engel olan ve öncelikli olarak aşılması gereken bariyerlerin tespit edilmesi için uygulanan ÇKKV yöntemlerinden PROMETHEE sonuçlarına yer verilecektir. Detaylı olarak yukarıda açıklanan tekniğin çalışmadaki uygulaması Visual grupları için tercih fonksiyonu Formül 3'de 
gösterilen "Olağan" olarak belirlenmiștir (Brans ve Vicke, 1985: 650-652). Başlangiç tablosu oluşturulurken her kullanıcı grubu bazında bariyerlerin yüzde dağılım değerleri kullanılmıştır. Başlangıç matrisi Tablo 6'da verilmiştir.

\subsubsection{Mobil Pazarlama Bariyerlerinin Grup Bazında Önceliklendirilmesi (PROMETHEE Uygulamasi)}

Yukarıdaki bölümde belirlenen ve tanımlanan potansiyel kullanıcı grupları bazında öne çıkan mobil pazarlama bariyerlerini ortadan kaldırmak adına karar alıcılara yön vermesi için PROMETHEE 1'den (alternatiflerin kısmi sıralaması ile önceliğinin belirlenmesi) yararlanılmıştır. Detaylı olarak yukarıda açıklanan tekniğin çalışmadaki uygulaması Visual PROMETHEE ile yapılmıştır. Uygulamada teorik olarak birbirine herhangi bir önceliği bulunmayan alternatiflere verilen ağırlık değeri birbirine eşit ve toplamları 1 olacak şekilde belirlenmiştir. Karar vericinin bir kriter için herhangi bir tercihi olmadığı durumunda bu fonksiyonu tercih etmek doğru olduğundan uygulamadaki kullanıcı grupları için tercih fonksiyonu Formül 3'de gösterilen "Olağan" olarak belirlenmiştir (Brans ve Vicke, 1985: 650-652). Başlangıç tablosu oluşturulurken her kullanıcı grubu bazında bariyerlerin yüzde dağılım değerleri kullanılmıştır.

Birinci Tip Tercih Fonksiyonu: $f(x)= \begin{cases}1, & x \leq 0 \\ 0, & x>0\end{cases}$

Başlangıç matrisi üzerinden yukarıda açıklandığı şekilde değerlendirilen bariyerler için pozitif ve negatif akım değerleri hesaplanmıştır. Her bariyer için +1 ve -1 arasında değişen bu değerin farkı alınarak net akım değerleri elde edilmiş ve Tablo 7'de gösterilmiştir. Şekil 2'de, Tablo 7'de yer alan akım değerlerine göre bariyerlerin önem sıralaması görselleştirilmiştir. Buna göre gruptan bağımsız olarak en önemli bariyerin "Satın alma işlemi sırasında verilen kişisel bilgilerin üçüncü şahıslarla paylaşılma riski”, önem derecesi en düşük olanın ise "Cep telefonunun özelliklerini kullanma zorluğu” olarak belirlendiği görülmektedir. Şekil 3'de her bariyerin kullanıcı grupları bazında katkısı görülmektedir. Grafikteki eksen akım değerlerini göstermekte, ilgili bariyeri temsil eden sütunun büyüklüğü etkinin derecesini ifade etmektedir. Her bariyerin sütununun üzerinde etki edeceği kullanıcı gruplarının isimleri bulunmaktadır. Örneğin ilk sütun yorumlanırsa;" Satın alma işlemi sırasında verilen kişisel bilgilerin üçüncü şahıslarla paylaşılma riski” bariyeri "Güvenliler" dışındaki tüm kullanıcı gruplarına etkisi bulunan bir bariyerdir. En yüksek etki seviyesi "Cep telefonunun özelliklerini kullanma zorluğu" olmakla birlikte etki ettiği gruplar sadece "Erken Benimseyenler" ve "Sıradışı" gruplarıdır.

$\mathrm{Bu}$ aşamada karar alıcılar stratejik aksiyonlarını etkinin genişliğine göre mi büyüklüğüne göre mi ya da her ikisini de göz önünde bulundurarak m1 planlayacaklarını belirleyebilirler. Analizin öne çıkan taraflarından bir tanesi de sadece bariyerlerin önem siralamasını vermesinden ziyade etki alanını da değerlendirmeye uygun olmasıdır.

VP programı aracılığı ile karar alıcılara sunulan farklı bir perspektif de GAIA düzlemi oluşturulmasıdır. Burada tüm kriter ve alternatifler iki boyutlu bir düzlem üzerine aktarılır. Çalışma kapsamında elde edilen sonuçlar aracılığı ile geliştirilen GAIA düzlemi Şekil 4'te görülebilir. GAIA düzlemi üzerinde bariyerler nokta, kullanıcı grupları ise vektör olarak gösterilmektedir. Ayrıca karar çubuğu
(Decision Stick) düzlem üzerinde orijinden çıkan kırmızı çubuk ile gösterilmektedir. Önceliklendirilmesi istenilen bariyerlerden "Satın alma işlemi sırasında verilen kişisel bilgilerin üçüncü şahıslarla paylaşılma riski" ve "Satın alınacak mal ve hizmetleri değerlendirme zorluğu yaşanması" karar çubuğunun gösterdiği istikamette olduklarından dolayı en iyi uzlaşıcı çözüm yönündedir denir. $\mathrm{Bu}$ bariyerlerin aksine karar çubuğunun aksi yönünde konumlanan "Telefon ekranının küçük olması" ve "Satın alınan mal ve hizmetlerin bedelini ödemede güvenlik açığı yaşanması" bariyerleri karar verici için seçim esnasında tercih edilmeyecek alternatifler olarak karşımıza çıkmaktadır. Kullanıcı gruplarını gösteren vektörlerin uzunluğu bu grubun ayrıştırıcı özelliği ve karar çubuğunu etkilemedeki önemini ifade eder. Ayrıştırma gücü az olanlar düzleme dik konumlanacağı için kısa görünecektir (Mareschal ve Brans, 1988:76).

Ayrıca "Satın alma işlemi sırasında verilen kişisel bilgilerin üçüncü şahıslarla paylaşılma riski" ve "Satın alınacak mal ve hizmetleri değerlendirme zorluğu yaşanması" bariyerleri GAIA düzlemi üzerinde aynı yönde ve göreceli olarak birbirlerine yakın konumda olduklarından profilleri de yakındır. Eğer bariyerlerin düzlem üzerinde bulundukları konum uzaksa sahip oldukları kriter değerleri arasındaki farkların büyük olduğu anlaşılır. Yine "Satın alma işlemi sırasında verilen kişisel bilgilerin üçüncü şahıslarla paylaşılma riski” ve "Satın alınacak mal ve hizmetleri değerlendirme zorluğu yaşanması" bariyerleri aynı yönde bulunan "Düzenli kullanıcılar" ve "Teknoloji meraklısı" grupları için diğerlerine göre daha yüksek puana sahiptir. Tersinden bakıldığında bu iki gruba uzak noktada bulunan "Telefon ekranının küçük olması" bu gruplar için düşük öneme sahiptir. Örnekte açıklandığ 1 şekilde probleme konu olan tüm bariyer ve kullanıcı gruplarının tüm mümkün göreceli değerlendirmeleri GAIA düzlemi yardımıyla kolaylıkla yapilabilmektedir.

\section{Sonuç ve Öneriler}

Son yıllarda tüm dünyada oldukça büyük bir hızla artan mobil araç kullanımı ile tüketiciler bu araçlara bağımlı hale gelmiş ve sonuç olarak da mobil pazarlama trend bir strateji olarak işletmeler tarafindan son 20 yılda en çok tercih edilen pazarlama stratejilerinden biri haline gelmiştir. Özellikle tüketici segmentasyonu mobil pazarlama stratejilerini derinden etkileyen bir etmen olarak belirlenmiştir. Dolayısıyla yapılan bu çalışmada yetişkin olarak tabir edilen tüketici segmentinin mobil pazarlamaya bakış açısı, algısı, değer yargıları, kullanım alışkanlıkları ve engelleri incelenerek, hem akademik anlamda pazarlama literatürü açısından önemli bulgulara rastlanmış, hem de işletmelerin sektörel anlamda yararlanabilecekleri birtakım veriler ortaya konulmuştur. Mobil pazarlama literatüründe hem müşteri segmentasyonu, hem müşterilerin kullanım alışkanlıkları, hem de yeni müşteri kazanımında alınacak aksiyonların belirlenmesine yönelik konular ayrı ayrı ele alınmaktadır (Kayıkçı vd., 2019; İspir ve Süher, 2009; Doğaner ve Kuyuculara, 2017, O'Regan, vd., 2011; Tsang, vd., 2004, 
Ström, vd., 2014; Chen, vd., 2019). Bu araştırmada farklı bakış açıları birleştirilmeye çalışılarak işletme profesyonellerinin stratejik karar sistemlerine direkt girdiler sunulması amaçlanmış ve bu bağlamda yöntem olarak çok kriterli karar verme tekniklerinden kullanımı ve sonuçlarının anlaşılması kolay olan PROMETHEE'den yararlanılmıştır.

Tablo 4. Faktör Analizi Sonuçları

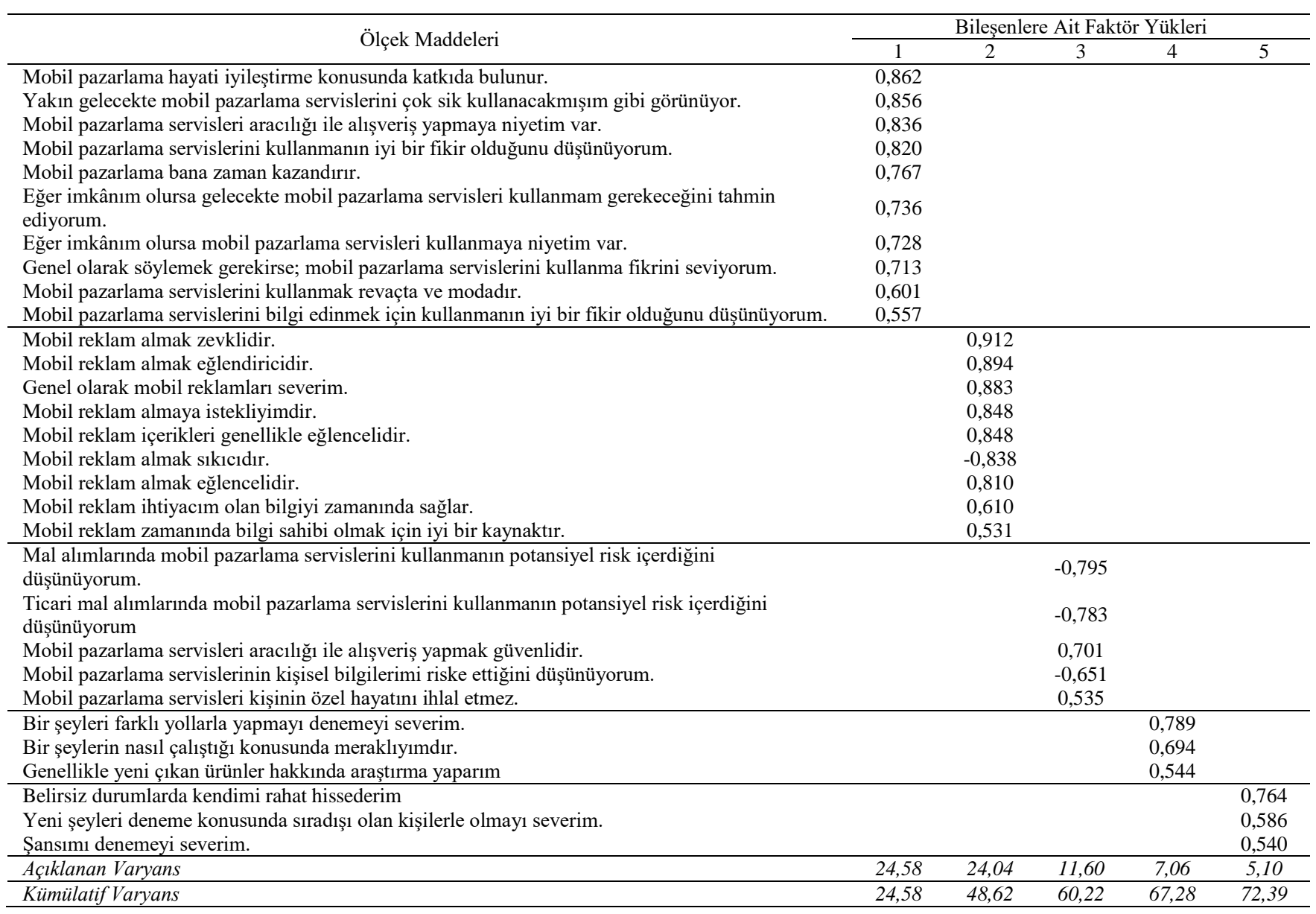

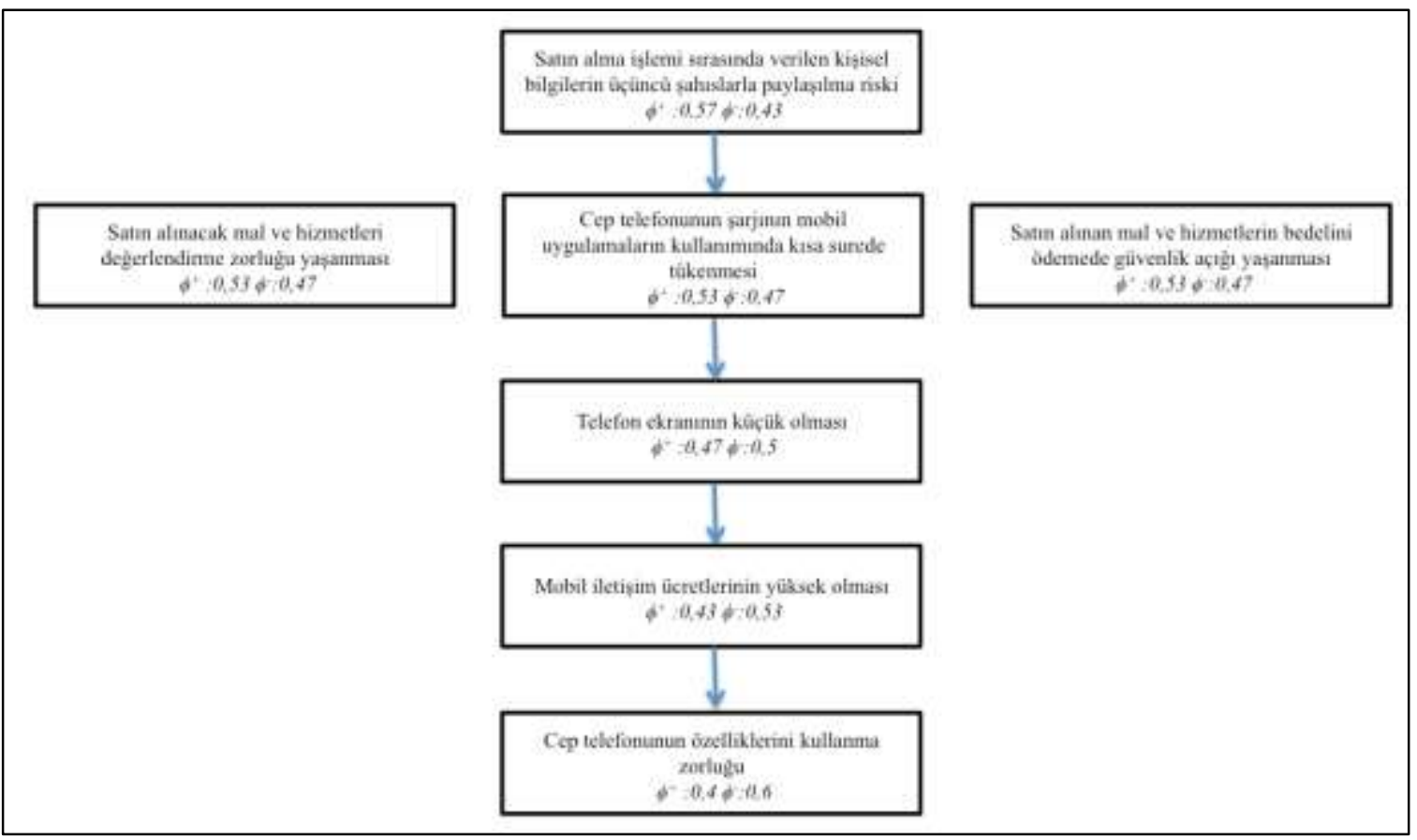


Tablo 5. Kullanıcı Grupları Bazında Özellikler

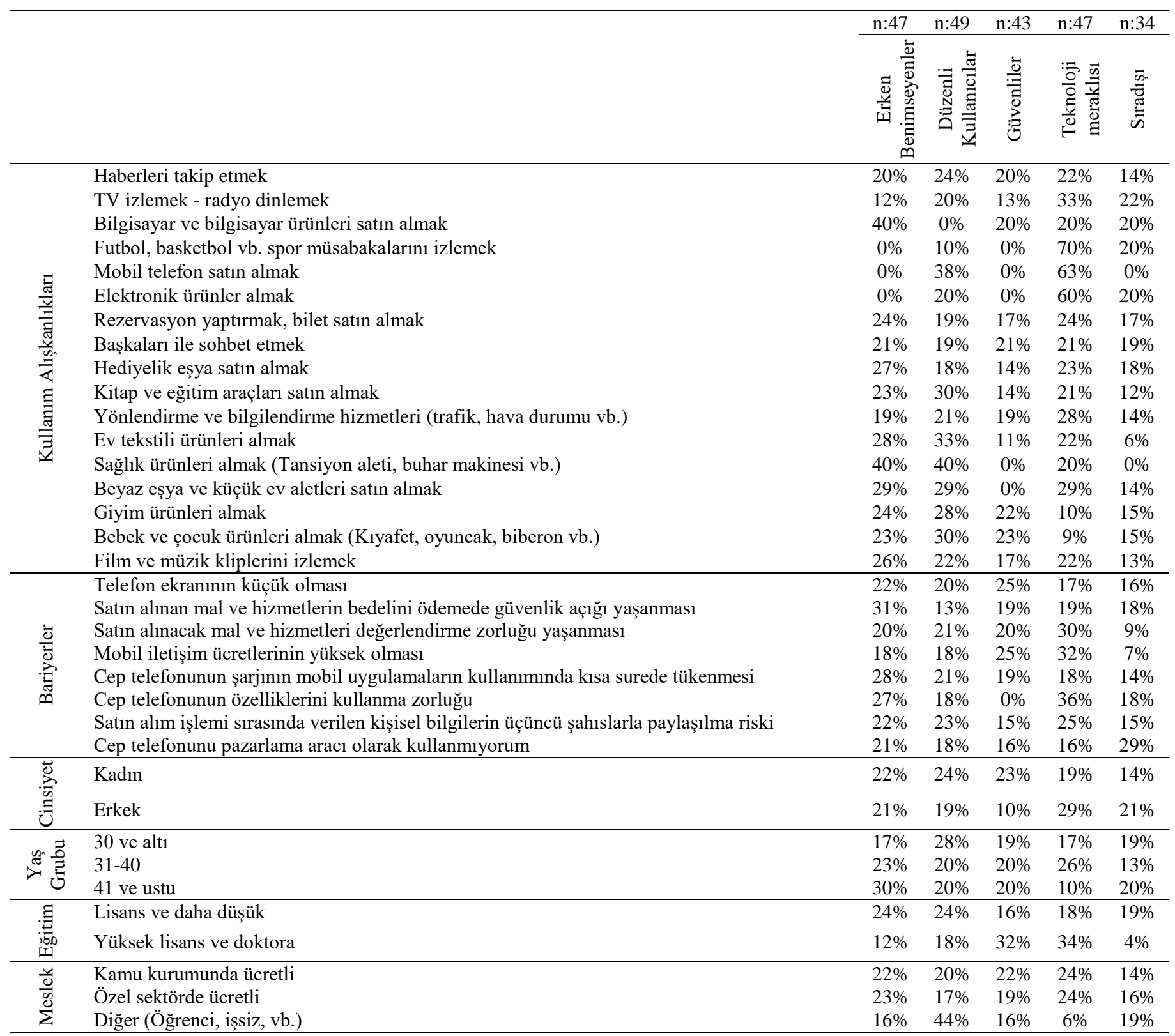

Tablo 6. PROMETHEE Başlangıç Tablosu

\begin{tabular}{|c|c|c|c|c|c|}
\hline & $\begin{array}{c}\text { Erken } \\
\text { Benimseyenler }\end{array}$ & $\begin{array}{c}\text { Düzenli } \\
\text { Kullanıcılar }\end{array}$ & Güvenliler & $\begin{array}{l}\text { Teknoloji } \\
\text { meraklısi }\end{array}$ & Sıradış1 \\
\hline Telefon ekranının küçük olması & 0,219 & 0,203 & 0,250 & 0,172 & 0,156 \\
\hline $\begin{array}{l}\text { Satın alınan mal ve hizmetlerin bedelini ödemede güvenlik açığı } \\
\text { yaşanması }\end{array}$ & 0,309 & 0,132 & 0,191 & 0,191 & 0,176 \\
\hline Satın alınacak mal ve hizmetleri değerlendirme zorluğu yaşanması & 0,200 & 0,214 & 0,200 & 0,300 & 0,086 \\
\hline Mobil iletişim ücretlerinin yüksek olması & 0,179 & 0,179 & 0,250 & 0,321 & 0,071 \\
\hline $\begin{array}{l}\text { Cep telefonunun şarjının mobil uygulamaların kullanımında kısa } \\
\text { surede tükenmesi }\end{array}$ & 0,278 & 0,208 & 0,194 & 0,181 & 0,139 \\
\hline Cep telefonunun özelliklerini kullanma zorluğu & 0,273 & 0,182 & 0,000 & 0,364 & 0,182 \\
\hline $\begin{array}{l}\text { Satın alma işlemi sırasında verilen kişisel bilgilerin üçüncü şahıslarla } \\
\text { paylașılma riski }\end{array}$ & 0,222 & 0,231 & 0,148 & 0,250 & 0,148 \\
\hline
\end{tabular}

Tablo 7. PROMETHEE Akım Tablosu

\begin{tabular}{|c|c|c|c|c|}
\hline Sira & Bariyerler & $\phi_{N E T}$ & $\phi^{+}$ & $\phi^{-}$ \\
\hline 1 & Satın alma işlemi sırasında verilen kişisel bilgilerin üçüncü şahıslarla paylaşılma riski & 0,1333 & 0,5667 & 0,4333 \\
\hline 2 & Satın alınacak mal ve hizmetleri değerlendirme zorluğu yaşanması & 0,0667 & 0,5333 & 0,4667 \\
\hline 3 & Cep telefonunun şarjının mobil uygulamaların kullanımında kısa surede tükenmesi & 0,0667 & 0,5333 & 0,4667 \\
\hline 4 & Satın alınan mal ve hizmetlerin bedelini ödemede güvenlik açı̆̆ı yaşanması & 0,0667 & 0,5333 & 0,4667 \\
\hline 5 & Telefon ekranının küçük olması & $-0,0333$ & 0,4667 & 0,5 \\
\hline 6 & Mobil iletişim ücretlerinin yüksek olması & $-0,1$ & 0,4333 & 0,5333 \\
\hline 7 & Cep telefonunun özelliklerini kullanma zorluğu & $-0,2$ & 0,4 & 0,6 \\
\hline
\end{tabular}




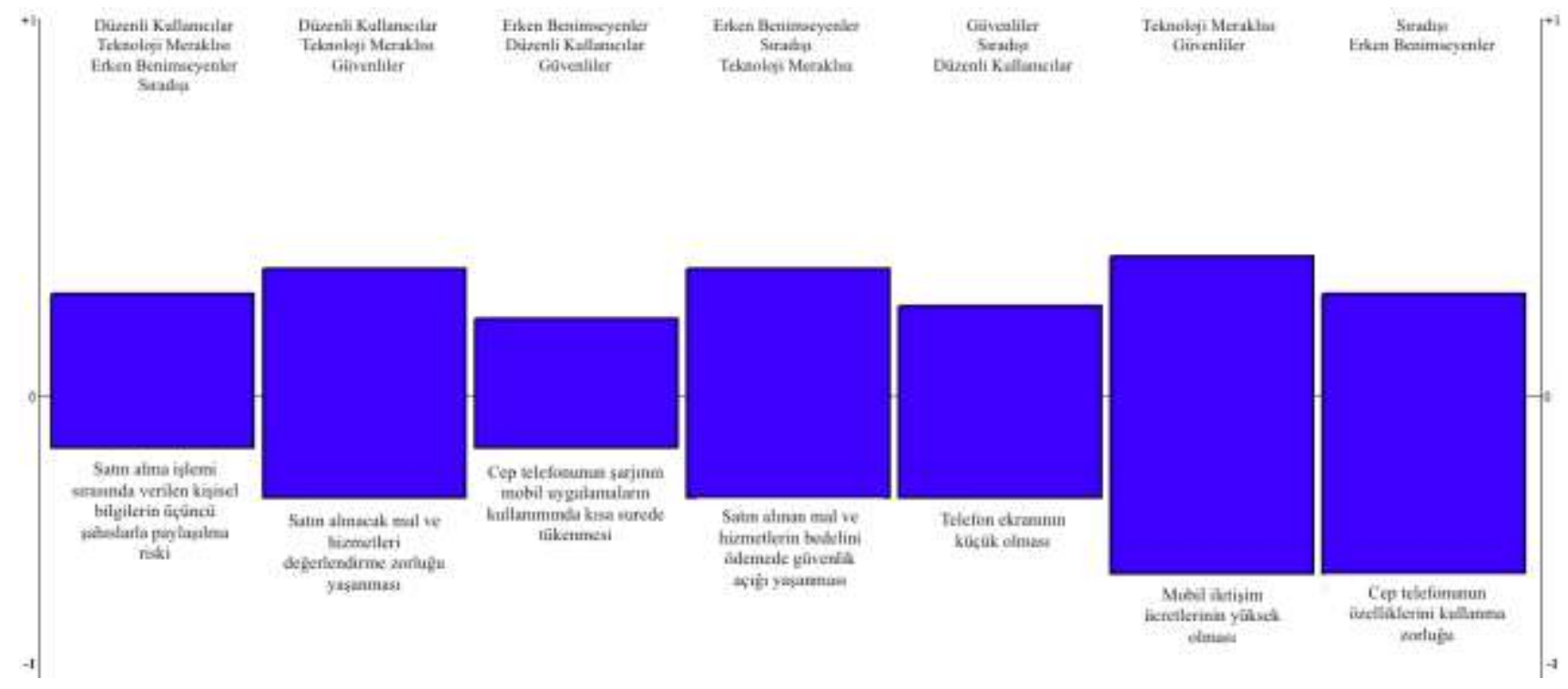

Şekil 3. Bariyerlerin Kullanıcı Grupları Bazında Etkileri

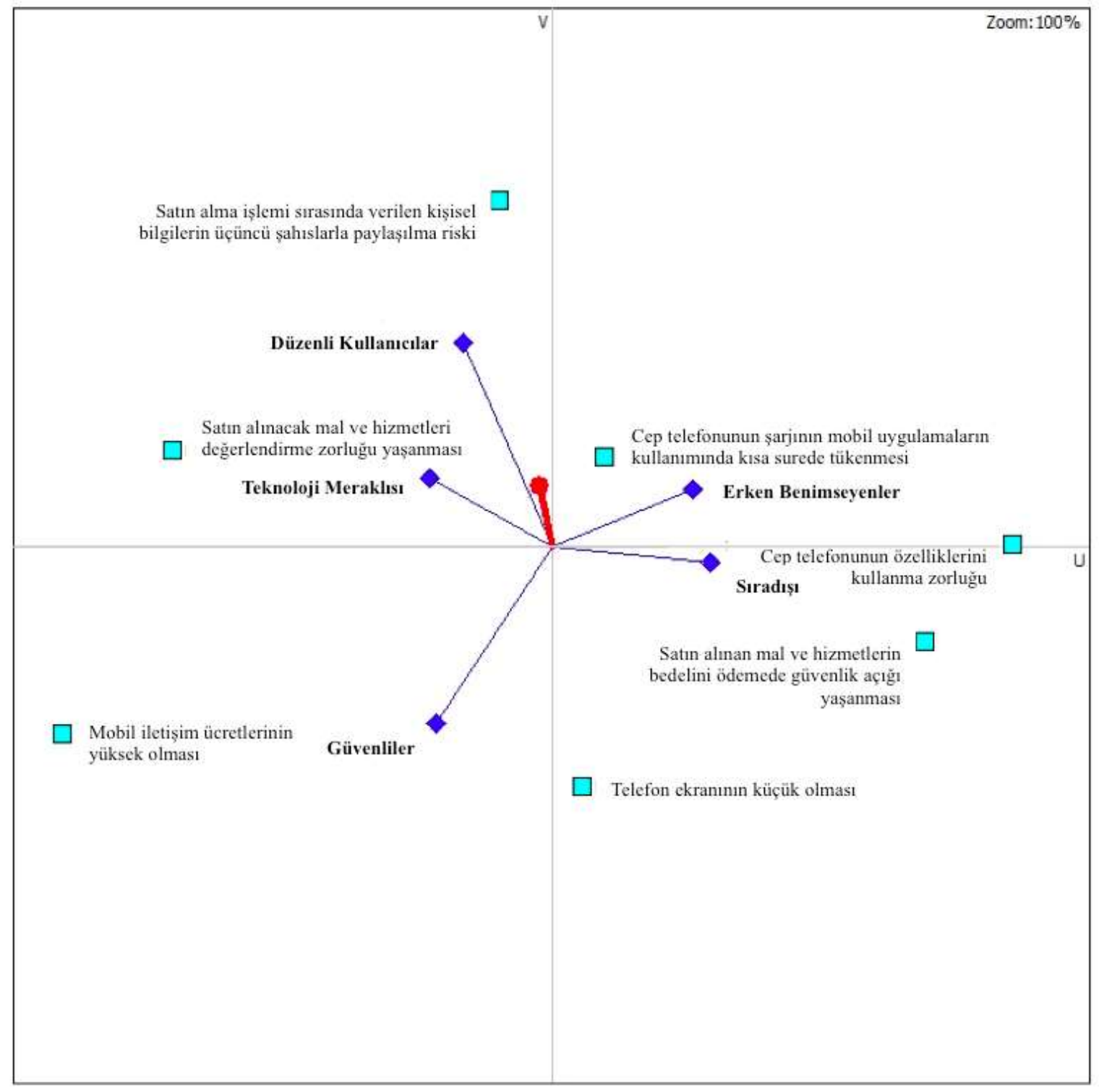

Şekil 4. GAIA Düzlemi

Elde edilen sonuçlara geniş bir perspektiften bakıldığında, hedef kitlesini belirleyen firmalar için yeni müşteri kazanımında aşmaları gereken bariyerler müşteri segmenti bazlı olarak önceliklendirilmiş olarak elde edilmiştir. 
İşletmeler katılımcıların özellikleri ve satın alma engellerini göz önünde bulundurarak, kendi hedef kitlelerine yönelik pazarlama stratejileri oluşturabilir, böylelikle engelleri kaldırabilecek ve yani algılar yaratabilecek imkânlar sağlayabilirler. Diğer taraftan bu girdiyle kural bazlı karar destek sistemlerini pazarlama çalışmalarında kullanan işletmeler için tanımlanacak aksiyonların alınacağı kitle de adreslenmiştir.

Çalışma kapsamında kullanım alıșkanlıklarına dair elde edilen sonuçlara bakıldığında; mobil araçlarla yapılan alışverişlerin sektör olarak en fazla olarak giyim, eğitim ve bebek ürünlerinde gerçekleştirildiği görülmüştür. Dolayısıyla bu sektörler yapacakları mobil stratejilerde daha çok yetişkin tüketici segmentine göre pazarlama faaliyetlerine (reklam, halkla ilişkiler vb. pazarlama iletişimi çalışmalarına) yer vermeleri gerekmektedir. Yapılan çalışmada bu satın alma davranışlarında tüketicilerin risk algılarına değinilerek, satın almayı engelleyici bariyerler belirlenmiş ve en fazla satın alma işlemi sırasında verilen kişisel bilgilerin üçüncü şahıslarla paylaşılma riski tüketiciler tarafından belirtilmiştir. $\mathrm{Bu}$ açıdan değerlendirildiğinde sektörel anlamda tüketicilerin risk algılarına, güvenli alışveriş ve kişisel bilgilerin korunmasına yönelik çalışmalar yapılabilir ve işletmeler satın alma bariyerlerini ortadan kaldırabilirler.

Çalışmada değinilen bir diğer nokta ise, araştırmaya katılan ve yetişkin segmentinde yer alan mobil araç kullanıcılarının kendi aralarında tutumlarına göre 5 farklı grupta incelenmesidir. Buna göre katılımcılar Erken Benimseyenler (Early Adopters), Düzenli Kullanıcılar (Regular Users), Güvenliler (Trustworthy), Teknoloji meraklısı (Geek) ve Sıradışı (Out-of-the-box) olarak gruplandırılmışlardır. Her bir gruplandırmada katılımcıların demografik özellikleri ve mobil araçları satın almada kullanma alışkanlıkları karşılaştırılmıştır. Erken Benimseyenler (Early Adopters) grubunda cinsiyetin ayırıcı bir özelliği olmadığı, genellikle 40 yaş ve üzeri kişilerin bulunduğu ve en çok bilgisayar ve elektronik eşya satın almak için kullandığı belirlenmiştir. $\mathrm{Bu}$ gruptaki satın alma konusundaki engeller ise başta güvenli alışveriş olmak üzere, cep telefonunun şarjının mobil uygulamaların kullanımında kısa surede tükenmesi ve cep telefonunun özelliklerini kullanma zorluğu öne çıkmaktadır. Daha çok genç yaş grubu kadın kullanıcıların ön planda olduğu Düzenli Kullanıcılar (Regular Users) grubunda da satın alma davranışını engelleyen faktör olarak satın alma işlemi sırasında verilen kişisel bilgilerin üçüncü şahıslarla paylaşılma riski karşımıza çıkmaktadır. Kadın katılımcıların çoğunlukta olduğu ve daha çok giyim üzerine satın alımların gerçekleştiği Güvenliler (Trustworthy) grubunda satın alma davranışında karşılaşılan engeller; telefon ekranının küçük olması ve Mobil iletişim ücretlerinin yüksek olması olarak belirlenmiştir. Daha çok 31-40 yaş arası (ve erkek kullanıcıların bulunduğu Teknoloji meraklısı (Geek) grubunda ise, mobil alışverişlerde teknolojik ürünlerin ön planda olduğu ve mobil iletişim ücretlerinin yüksek olması ve satın alınacak mal ve hizmetleri değerlendirme zorluğu yaşanması gibi engellerin satın alma davranışlarını etkilediği saptanmıştır. Son olarak da düşük eğitim seviyesine sahip 30 yaş altı ve 41 yaş üstü erkek kullanıcılar oluşturduğu Sıradışı (Out-of-the-box) katılımcı grubunda ise, genellikle mobil araçlara ürün satın almak için yönelmedikleri, sadece iletişim amaçlı kullandıkları belirlenmiştir.
Araştırma, belirtilen tarihler arasında ulaşılabilen örneklem ve bu kitlenin oluşturulan veri toplama aracına kendi özgür iradeleri ile verdikleri cevaplar ile sınırlıdır. Daha geniş uzam içerisinde örneklem hacmi arttırılarak elde edilen sonuçların daha geniş kitleye genellenmesi sağlanabilir. Konu ile ilgili yapılacak gelecek çalışmalarda farklı yaş grupları ele alınarak farklı potansiyel hedef kitle profilleri üzerinden araştırma yapılabilir. Yanı sıra ele alınan konunun teknolojik gelişmelere bağlı olarak güncelliğini kısa periyotlarda kaybetmesi nedeniyle mobil pazarlama teknolojisindeki yenilikler de kapsanarak yenilenmesi önerilmektedir.

\section{Kaynakça}

Barutçu, S. (2011). Mobil Viral Pazarlama, Internet

Uygulamalarl ve Yönetimi Dergisi, 2(1), 5-13.

Barutçu, S., \& Öztürk M. (2009) Mobil Reklamlar ve Mobil Reklam Araçlarına Yönelik Tutumlar. KMU IIBF Dergisi, 11(17), 24-41.

Brans, J.P. (1982). L'ingenierie de la decision: Elaboration d'instruments d'aide a la decision. La Methode PROMETHEE, Universite Laval, Colloque d'aide a la Decision, Quebec, Canada, 183-213.

Brans, J. P., \& Vincke, P. (1985). A Preference Ranking Organization Method: The PROMETHEE Method for MCDM, Management Science, 31(6), 647-656.

Bozacı,İ. \& Beğdeş, N. R. (2019). Konum Tabanlı Mobil İletişimlerin Benimsenmesini Etkileyen Faktörler Üzerine Bir Araştırma (A Research on the Factors Affecting Adaption of Location Based Mobile Communications). Iş̧letme Araştırmaları Dergisi. Journal Of Business Research-Turk. 2019, 11(3), 20842093.

Bölen,M.C., Damar, M., Özdağoğlu, G., \& Özdağoğlu, A. (2018). Mobil Sosyal Ağlar Üzerine Küresel Ölçekte Yapılan Yayınların Değerlendirilmesi: Bilimetrik Bir Araştırma, 5th International Management Information Systems Conference. October 24-26 2018, Ankara. 9399.

Chen, Q., Lu, Y., \& Tang, Q. (2019). Why do users resist service organization's brand mobile apps? The force of barriers versus cross-channel synergy. International Journal of Information Management, 47, 274-282.

Dağ, S., \& Yıldırım, B.F. (2015). PROMETHEE, (Çok Kriterli Karar Verme Yöntemleri içinde), Ed: Bahadır Fatih Yıldırım, Emrah Önder, Dora Yayınları, Bursa.

Doğaner, M., \& Kuyuculara, Y. (2017). Mobil Reklam Faaliyetlerinin Tüketici Algısı Üzerine Etkileri: Üniversite Öğrencilerine Yönelik Bir Araştırma, Adnan Menderes Üniversitesi Sosyal Bilimler Enstitüsü Dergisi, 4(3), 236-255.

Dündar, S., Ecer, F., \& Özdemir, Ş. (2007). Fuzzy Topsis Yöntemi İle Sanal Mağazaların Web Sitelerinin Değerlendirilmesi. Atatürk Üniversitesi İktisadi ve Idari Bilimler Dergisi, 21(1), 287-305. 
Gårdlund, M. (2005). A Conceptual Model of Mobile Marketing for a Multinational Consumer Goods Company. KTH Information and Communication Technology, Master of Science Thesis, Stockholm, Sweden.

Genç, T. (2013). PROMETHEE Yöntemi ve GAIA Düzlemi. Afyon Kocatepe Üniversitesi İ̈BF Dergisi, 15(1), 121142.

Göral, R. (2015). E-WOM'a Dayalı Çok Kriterli Karar Verme Teknikleri İle En Uygun Otelin Belirlenmesi ve Bir Uygulama. Selçuk Üniversitesi Sosyal Bilimler Enstitüsü Dergisi, 33, 1-17.

Haghirian, P., \& Dickinger, A. (2004). Identifying Success Factors of Mobile Marketing. Association of Consumer Research. 17(1), 8-13.

Hesselborn, O., \& Freemuth, N. (2005), The Basic Book of Mobile Marketing. Best Practices and Results, 1.Bask1, Ocean Seven Consulting, München.

İspir, N., \& Suher, H. (2009). Sms Reklamlarına Yönelik Tüketici Tutumları. Selçuk Üniversitesi İletişim Fakültesi Akademik Dergisi, 5(4), 5-17

Kalburan, Ç. (2018). Tüketici Algılarına Ait Çok Kriterli Karar Verme Verisinin Çok Boyutlu Ölçekleme Yönteminde Kullanımı: Cep Telefonu Markaları Örneği. Pazarlama ve Pazarlama Araştırmaları Dergisi, 22, 171185.

Karagöz, Y. (2015). SPSS 22 Uygulamall Biyoistatistik, 2. Basım, Ankara, Nobel Yayınevi.

Karasar, N. (2005). Bilimsel Araştırma Yöntemi. 3A Araştırma Eğitim Danışmanlık Ltd. Şirketi, Ankara.

Kayıkçı, P., Armağan, K., \& Dal, N.E. (2019). Mobil Alışveriş Uygulamaları Bildirimlerine Karşı Tüketici Tutumları Hakkında Bir Araştırma (A Study on Consumer Attitudes Against Mobile Shopping Applications Notifications). İşletme Araştırmalart Dergisi Journal Of Business Research-Turk, 11(3), 2040-2058.

Mareschal, B., \& Brans, J.P. (1988).Geometrical Representations for MCDA, European Journal of Operational Research, 34, 69-77.

Mareschal, B., \& Smet, Y.D. (2009). Visual PROMETHEE: Developments of the PROMETHEE \& GAIA multicriteria decision aid methods. 2009 IEEE International Conference on Industrial Engineering and Engineering Management, 1646-1649.

McDonald, M., \& Dunbar, I. (2004). Market Segmentation: How to do it, How to Profit from it. Elsevier ButterworthHeinemann, Italy.

Michael, A., \& Salter, B. (2006). Mobile Marketing: Achieving Competitive Advantage through Wireless Technology. Elsevier Ltd., Oxford, United Kingdom.

Nester, K., \& Lyall, K. (2003). Mobile Marketing-A Primer Report, First Partner Research \& Marketing.(Erişim: 06.09.2018), http://www.mics.ch/SumIntF04/SandrineDebetaz.pdf.
O'Regan, M., Ashok, K., Maksimova, O., \& Reshetin, O. (2011). Optimizing Market Segmentation For A Global Mobile Phone Provider For Both Targeting And Insight. Journal Of Advertising Research, 51(4), 571577.

Özdamar, K. (2016). (2013). Paket Programlar İe Istatistiksel Veri Analizi, Cilt 2, Nisan Kitapevi, Ankara.

Scharl, A., Dickenger, A., \& Murphy, J. (2005). Diffusion and Success Factors of Mobile Marketing, Electronic Commerce Research and Applications, 4, 159-173.

Steenkamp, J.B.E., \& Ter Hofstede, F. (2002). International Market Segmentation: Issues and Perspectives. International Journal of Research in Marketing, 19(3), 185-213.

Ström, R., Vendel, M., \& Bredican, J. (2014). Mobile marketing: A literature review on its value for consumers and retailers. Journal of Retailing and Consumer Services, 21(6), 1001-1012.

Şahin, E. \& Dündar, M. (2019). Sosyal Ağ ve Sosyal Medya Platformları Üzerinde Yürütülen Viral Pazarlama Faaliyetlerinin Tüketici Davranışı Üzerindeki Etkisi: İstanbul İli Örneği. Selçuk Üniversitesi Sosyal Bilimler Meslek Yüksekokulu Dergisi. 22 (1), 143-160

Tabachnick, B.G., \& Fidell, L.S. (2013). Using Multivariate Statistics. Pearson, Boston.

Terzi, O., \& Kızgın, Y. (2017). Mobil Pazarlama Uygulamalarının $\quad \mathrm{Y}$ Kuşağı Açısından Değerlendirilmesi: Muğla İli Örneği. Sosyal ve Beşeri Bilimler Araştırmaları Dergisi, 19(40), 199-219.

Tsang, M., Ho, S., \& Liang, T. (2004). Consumer Attitudes Toward Mobile Advertising: An Empirical Study. International Journal of Electronic Commerce, 8(3), 65-78.

Uyar, A. (2019). Tüketici'nin Mobil Uygulamalar Hakkındaki Algılarının Teknoloji Kabul Modeline Göre Değerlendirilmesi. İşletme Araştırmaları Dergisi. 11/2019. 687-705

Wedel, M., \& Kamakura, W.A. (2000). Market Segmentation: Conceptual and Methodological Foundations. Kluwer Academic Publishers, Dordrecht/Boston/London.

Wind, J., \& Bell, D. (2007). Market Segmentation. In: The Marketing Book, Taylor \& Francis, London.

Xu, D., Liao, S. \& Li, Q. (2008). Combining Empirical Experimentation And Modeling Techniques: A Design Research Approach For Personalized Mobile Advertising Applications. Decisions Support Systems, 44, 710-724.

Yılmaz, M.K., Başar, E.E., \& Pabuçcu, H. (2015). Pazarlama Kaynaklarına En Uygun Rekabetçi Pazarlama Stratejisinin Belirlenmesi: Kış Turizmi Otellerine Yönelik Bir Uygulama. Ege Akademik Bakış, 15(3), 409-419.. 